Journal of Extension Education

Vol. 28 No. 2, 2016

\title{
Subject Matter Specialists and Organizational Effectiveness of Krishi Vigyan Kendras of Tamil Nadu and Kerala
}

\author{
Bimal P Bashir ${ }^{1}$, N. Narmatha ${ }^{2}$ and K.M. Sakhtivel ${ }^{3}$
}

\begin{abstract}
The study was undertaken with the objective of determining the socio-personal characteristics of Subject Matter Specialists (SMS) of Krishi Vigyan Kendra (KVK) and their relationship with organizational effectiveness. Altogether 65 SMS' from 12 KVKs across Tamil Nadu and Kerala were selected. The study has concluded that most of respondents were middle aged with more than half of them being female. Majority of them was married, had work experience of below five years and had attended three to five trainings. Most of the respondents had high level of job satisfaction team-work and one-fourth felt a medium to high job stress. More than half of the respondents felt medium level of work load. There was a positive and significant correlation at one per cent level between job satisfaction / team work and organizational effectiveness of KVKs whereas job stress had a negative and significant correlation at five per cent level. Hence it may be concluded that team work, job satisfaction and job stress play a significant role in improving the organizational effectiveness of KVK. More emphasis must be given for team building enhance the job satisfaction level and reduce the job stress among Subject Matter Specialists of KVKs.
\end{abstract}

Key words: Job satisfaction, team work, job stress, subject matter specialists, Krishi Vigyan Kendra

\section{INTRODUCTION}

Krishi Vigyan Kendras (KVKs) are organizations meant for application of technology through assessment, refinement and demonstration of proven technologies under different 'micro farming situations in a district. Organizational effectiveness of KVKs plays a pivotal role in effective delivery of its services to the extension system. It reflects how effectively an organization can discharge its function with respect to all of its constituents in its internal and external environment (Pathak \& Patwardhan, 2011). A study on personal profile of Subject Matter Specialists and organizational effectiveness of KVK will provide a better insight into the

1.Ph.D Scholar \& 2. Professor and Head, Department of Veterinary and Animal Husbandry Extension, Veterinary College and Research Institution, Namakkal - 637002 and 3. Professor, Department of Veterinary and Animal Husbandry Extension, Veterinary College and Research Institute, Orathanadu - 641625. 
Subject Matter Specialists and Organizational Effectiveness of Krishi Vigyan Kendras of Tamil Nadu and Kerala

functioning of KVKs. It will be useful for policy makers and expert officials while setting administrative reforms in KVKs. Keeping these things in view, the objectives were set to study the sociopersonal characteristics of subject matter specialists of Krishi Vigyan Kendras and their relationship with organizational effectiveness.

\section{METHODOLOGY}

\section{Selection and Description of Krishi Vigyan Kendras}

The study was undertaken during 2012-2014. During the time there were 641 Krishi Vigyan Kendras functioning in India, managed through eight different zones. The eighth zone comprises Tamil Nadu, Kerala, Karnataka, Goa, Pondicherry and Lakshadweep. Tamil Nadu and Kerala were purposively selected based on familiarity of the researcher with study area and language. In Tamil Nadu, there are 30 Krishi Vigyan Kendras and Kerala is having 14 Krishi Vigyan Kendras. Out of the total 30 Krishi Vigyan Kendras in Tamil Nadu, 19 are hosted by State Universities / Deemed Universities and 11 are hosted by Non-Government Organisations (NGO), whereas out of 14 Krishi Vigyan Kendras in Kerala, 11 are hosted by State Universities / ICAR (Indian Council of Agricultural Research) institutes and three are hosted by Non-Government Organizations. A list of KVKs in Tamil Nadu and Kerala which were established during or before 2004 was prepared. From the list, three state university KVKs and three NGO KVKs from each state were randomly selected for the study.

\section{Selection of Respondents}

All Subject Matter Specialists of Krishi Vigyan Kendras were selected for the study. Thus, a total of 65 Subject Matter Specialists constituted the sample for the study.

Selection, operationalizaiton and measurement of variables concerning the characteristics of subject matter specialists

Organizational effectiveness being a psychological variable and in order to have a deep understanding of it, an attempt has been made to analyze the socio-personal profile and working environment of SMS in addition to various components of organizational effectiveness. The socio-personal variables studied include - Age, Gender, Marital status, Education, Trainings attended, Field of specialization, Work experience, Transportation facilities and Linkage with other development institutions.

\section{Method of Data Collection}

Taking into consideration of the scope and objectives of the study, a well-structured interview schedule was prepared for subject matter specialists. Before finalizing the interview schedule, 
it was pre-tested in a non-sample area to probe into the relevancy of the schedule to suit the areas under study. Based on the results of pre testing, suitable modifications were made and a final interview schedule was prepared. The data were collected from the subject matter specialists by making personal visits.

\section{Statistical Tools used}

The data collected from the subject matter specialists were coded, compiled and analyzed using frequency, percentage, mean, equal class interval, Delinious-Hodges cumulative method of classification, Pearson correlation analysis and multiple linear regression analysis. The data were analyzed with the help of Statistical Package for the Social Sciences (Ver.17).

\section{FINDINGS AND DISCUSSION}

\section{Socio-personal characteristics of Subject Matter Specialists in Krishi Vigyan Kendras}

An analysis of characteristics of the subject matter specialists in Krishi Vigyan Kendras was done in order to get better understanding about their background.

\section{Age}

Two-thirds of the respondents (66.00 per cent) were in middle age group, 26.00 per cent of them were in young age group and 8.00 per cent were in old age group. This finding derives support from the findings of Tayade et al. (2011).

\section{Sex and Marital Status}

More than half of the respondents (57.00 per cent) were female. Majority (88.00 per cent) of the respondents was married.

\section{Education}

More than two-thirds of the respondents (69.00 per cent) had post graduation followed by doctoral degree (26.00 per cent) and graduation (5.00 per cent). The probable reason attributed to this might be that minimum qualification for the subject matter specialists as specified by ICAR is Master's degree in the respective subject. This finding is in conformity with the findings of Jyothi (2006).

\section{Trainings Attended}

More than two-thirds of the respondents (45.00 per cent) attended three to five trainings followed by one to two trainings (34.00 per cent) and six or more trainings (21.00 per cent). This finding derives support from the findings of Tayade et al., (2011). Because of technological advancement, frequent trainings are needed to enhance the efficiency of human resources and to improve the capabilities of staff members. Deputing SMS' for attending various trainings, workshops etc. would increase the overall performance of SMS' 
and in turn improve the organizational effectiveness of the KVK.

Field of Specialization

Among the respondents studied, 18.00 per cent of them were specialized in veterinary / animal sciences followed by 17.00 per cent in agronomy, 15.00 per cent each in home science and horticulture, 12.00 per cent in entomology / plant pathology, 6.00 per cent in soil science, 5.00 per cent each in extension, fisheries and agricultural engineering and 2.00 per cent in plant breeding.
As per the guidelines, the programme co-coordinator of KVK is preferably an extension scientist or at least one SMS should be an extension specialist in each KVK. Out of $12 \mathrm{KVKs}$ studied, only one KVK was headed by extension specialist and three KVKs had SMS' specialized in extension. Giving importance to extension scientists would help to develop location specific technology dissemination methodologies in the changing context of agriculture.

Table-1.

Linkages with Other Development Institutions

\begin{tabular}{|c|c|c|c|c|c|c|c|c|c|}
\hline \multirow{2}{*}{$\begin{array}{l}\text { S1. } \\
\text { No. }\end{array}$} & \multirow{2}{*}{ Category } & \multicolumn{2}{|c|}{ Excellent } & \multicolumn{2}{|c|}{ Good } & \multicolumn{2}{|c|}{ Satisfactory } & \multicolumn{2}{|r|}{ Poor } \\
\hline & & $\mathbf{F}$ & $\%$ & $\mathbf{F}$ & $\%$ & $\mathbf{F}$ & $\%$ & $\mathbf{F}$ & $\%$ \\
\hline 1. & $\begin{array}{l}\text { Agricultural } \\
\text { department }\end{array}$ & 28 & 43.08 & 33 & 50.77 & 4 & 6.15 & 0 & 0 \\
\hline 2. & $\begin{array}{l}\text { Agricultural } \\
\text { university }\end{array}$ & 24 & 36.92 & 38 & 58.46 & 2 & 3.08 & 1 & 1.54 \\
\hline 3. & $\begin{array}{l}\text { Animal } \\
\text { Husbandry } \\
\text { department }\end{array}$ & 16 & 24.62 & 26 & 40.00 & 20 & 30.77 & 3 & 4.61 \\
\hline 4. & $\begin{array}{l}\text { Veterinary } \\
\text { university }\end{array}$ & 19 & 29.23 & 24 & 36.92 & 19 & 29.23 & 3 & 4.62 \\
\hline 5. & NGOs & 12 & 18.46 & 34 & 52.31 & 18 & 27.69 & 1 & 1.54 \\
\hline 6. & Investors & 1 & 1.54 & 20 & 30.77 & 35 & 53.85 & 9 & 13.84 \\
\hline 7. & Local bodies & 7 & 10.77 & 37 & 56.92 & 21 & 32.31 & 0 & 0 \\
\hline 8. & NABARD & 19 & 29.23 & 31 & 47.69 & 11 & 16.92 & 4 & 6.16 \\
\hline 9. & $\begin{array}{l}\text { Lead Bank of the } \\
\text { District }\end{array}$ & 9 & 13.85 & 29 & 44.61 & 20 & 30.77 & 7 & 10.77 \\
\hline
\end{tabular}




\section{Work Experience}

More than two-fifths (43.00 per cent) of the respondents had below 5 years of experience followed by 6-10 years (32.00 per cent) and 11 years and above (25.00 per cent). Most of the respondents are young and middle aged, hence they are having less work experience.

\section{Transportation Facilities}

Among the respondents studied, more than half (52.31 per cent) of the respondents had their own four wheelers for transportation followed by both two as well as four wheelers (29.23 per cent) and two wheelers only (17.47 per cent).

\section{Linkage with Other Development Institutions}

Around three-fourths of $(74.00$ per cent) (Table 1) of the respondents had medium level of linkage with other development institutions, followed by high (17.00 per cent) and low (9.23 per cent) respectively. It also indicates that 43.00 per cent and 37.00 per cent of the respondents had excellent linkage with agricultural departments and agricultural universities respectively whereas 37.00 per cent to 56.00 per cent of respondents had good linkage with animal husbandry departments, veterinary universities, NGOs, local bodies and NABARD (National Bank for Agriculture \& Rural Development). It was also noted that 13.84 per cent and 10.77 per cent of respondents had poor linkage with investors and lead banks.
The strong linkage of KVK personnel with the state agricultural departments might be due to the fact that most of the development schemes, agricultural schemes in particular are being operated by the State department of Agriculture.

\section{Working Environment Prevailing in Krishi Vigyan Kendras}

Majority (47.69 per cent) of the respondents were moderately satisfied with the people's participation followed by high (41.54 per cent) and low (10.77 per cent) levels. In the domain of team work, 66.15 per cent of the respondents had high level of satisfaction in team work followed by medium (23.08 per cent) and low (10.77 per cent) levels. More than half (52.31 per cent) of the respondents had high level of satisfaction in the job followed by medium (41.54 per cent) and low (6.15 per cent) levels of satisfaction.

More than three-fourths $\mathbf{( 7 5 . 3 8}$ per cent) of the respondents felt that there was a low level of job stress followed by medium (23.08 per cent) and high (1.54 per cent) levels. The present findings gain support from the finding of Jyothi (2006). More than half of the respondents (55.38 per cent) felt that the work load was medium followed by high (40.00 per cent) and low (4.62 per cent). This finding gains support from the finding of Sandika (2006). 
Subject Matter Specialists and Organizational Effectiveness of Krishi Vigyan Kendras of Tamil Nadu and Kerala

Relationship

independent

variables

between

and organizational effectiveness among the Subject Matter Specialists of Krishi Vigyan Kendra

In order to understand the association between the characteristics of Subject Matter Specialists and their perception about the organizational effectiveness of Krishi Vigyan Kendras, Pearson correlation analysis was carried out and the results are presented in Table 2.

It could be seen from the table that out of 13 independent variables studied, satisfaction with people's participation and team work had positive and significant relationship at 1 per cent level. Job stress had negative and

Table-2.

Correlation between Independent Variables and Organizational Effectiveness among the Subject Matter Specialists of Krishi Vigyan Kendra

\begin{tabular}{|c|l|c|}
\hline \multirow{2}{*}{ Variable No. } & \multicolumn{1}{|c|}{ Variable } & $\begin{array}{c}\text { Overall } \\
\text { Organizational } \\
\text { Effectiveness }\end{array}$ \\
\cline { 3 - 3 } & & 'r' values \\
\hline X1 & Age & 0.027 \\
\hline X2 & Sex & 0.156 \\
\hline X3 & Marital status & -0.045 \\
\hline X4 & Educational level & 0.083 \\
\hline X5 & Working experience & -0.043 \\
\hline X6 & Number of training attended & -0.119 \\
\hline X7 & Transportation facilities & 0.029 \\
\hline X8 & Linkage with other developmental institutions & 0.095 \\
\hline X9 & Satisfaction with people's participation & 0.184 \\
\hline X10 & Satisfaction with team work & $0.333^{* *}$ \\
\hline X11 & Satisfaction with job & $0.601^{* *}$ \\
\hline X12 & Job stress & $-0.286^{*}$ \\
\hline X13 & Work-load & -0.012 \\
\hline
\end{tabular}

** Significant at 1 per cent level, * Significant at 5 per cent level 
significant relationship at 5 per cent level.

The relationship between stress and job satisfaction is interrelated and found to be negatively correlated, where stress is an emotional, physical reaction generated because of a situation, person or environment whereas job satisfaction is the end state of feeling, the feeling that is experienced after a task is accomplished (Jui-chen, 2006). The study has showed that Job stress and job satisfaction definitely decide the level of commitment of Subject Matter Specialist of KVKs which in turn decides organizational effectiveness.

Teamwork can also help in accomplishing the organizational duties. Reduction of human errors and promotion of job satisfaction are the outcome of teamwork, while in complex and stressful environments it is teamwork that can help in providing a safe working condition (Benrazavi and Silong, 2013). The results of this study depict the importance of team work and its influence over organizational effectiveness of KVKs.

\section{Contribution of Independent Variables towards the Organizational Effectiveness of Krishi Vigyan Kendras}

In order to find out which of the independent variables explained the influence over dependent variables and also to know the extent of their contribution made by these variables, multiple regression analysis was carried out. Among the 13 variables, based on correlation co-efficient value six

Table- 3.

Regression Analysis of Organizational Effectiveness with Selected Independent Variables

\begin{tabular}{|c|l|c|c|c|}
\hline \multirow{2}{*}{$\begin{array}{c}\text { S1. } \\
\text { No }\end{array}$} & \multicolumn{1}{|c|}{ Variables } & \multicolumn{2}{c|}{ Overall Organizational effectiveness } \\
\cline { 2 - 5 } & \multicolumn{1}{|c|}{$\begin{array}{c}\text { Partial } \\
\text { Regression } \\
\text { Co-efficient }\end{array}$} & $\begin{array}{c}\text { Standard } \\
\text { Error }\end{array}$ & $\begin{array}{c}\text { 't' } \\
\text { Value }\end{array}$ \\
\hline 1 & Sex & 15.189 & 18.117 & 0.838 \\
\hline 2 & $\begin{array}{l}\text { Linkage with other } \\
\text { development institutions }\end{array}$ & 2.030 & 2.256 & 0.900 \\
\hline 3 & Team work & -2.788 & 5.279 & -0.528 \\
\hline 4 & Job satisfaction & 10.094 & 2.329 & $4.334^{* *}$ \\
\hline 5 & People's participation & 1.485 & 4.777 & 0.311 \\
\hline 6 & Job stress & -0.355 & 1.237 & -0.287 \\
\hline & \multicolumn{2}{|c|}{$\mathrm{R}$ square $=.382, \mathrm{~F}=5.986^{* *}$} & \\
\hline
\end{tabular}

** Significant at 1 per cent level 
variables have been included for multiple regression analysis. The results are presented in Table 3.

It could be observed that all the selected independent variables put together could explain 38.20 per cent of variation in perception of Subject Matter Specialists on organizational effectiveness of Krishi Vigyan Kendras. Among the six variables taken for analysis, only one variable viz. job satisfaction was found to be positively significant at 1 per cent level. From the results it could be stated that a unit increase in the job satisfaction variable would correspondingly increase the perception of SMS' on organizational effectiveness of Krishi Vigyan Kendras by 10.094 units. This finding reinforces the general feeling that employees who are satisfied with their jobs would help in improving the effectiveness of organizations.

\section{CONCLUSION}

The present study underlines the importance of job satisfaction and team work among SMS' in Krishi Vigyan Kendras. A significant and positive correlation was observed between job satisfaction / team work and organizational effectiveness of KVKs. The study also stresses the need of reducing the job stress among SMS' in order to improve the overall efficiency of KVKs as a farmers' institution. Proper management of work force must be ensured by the policy makers for better organization effectiveness of KVKs.

\section{REFERENCES}

Benrazavi, S.R \& Silong, A.D. (2013). Employees Job Satisfaction and Its Influence on Willingness to work in Team. Journal of Management Policy and Practice, 14(1):127-140.

Jui-Chen, C.Y. (2006). Organization communication, job stress, organizational commitment and job performance of accounting professionals in Taiwan and America. Leadership \& Organization Development Journal, 27(4):242-249.

Jyothi, V. (2006). Decision Making Process of Krishi Vigyan Kendras (KVKs) in Northern Karnataka. Unpublished Ph.D. thesis, University of Agricultural Sciences, Dharwad, Karnataka, India.

Matteson, M.T \& Ivancevich. (1982). Managing Job Stress and Health. The Free Press, New York.

Pathak, R \& Patwardhan, M. (2011). Impact of Job Involvement on Organizational Effectiveness: A Study among Faculty Members. Prabadhan Indian Journal of Management, 4, (5) 36-42.

Prasad, M.S \& Mahipal. (1997). Impact of Training Programme on Knowledge Gain of Subject Matter Specialists. Journal of Extension Education, 8 (5) 1596-1599. 
Sandika, A.L. (2006). A Study on Organizational Climate Perception by Veterinary Officers (VOs) and Veterinary Livestock Inspectors (VLIs) of Department of Animal Husbandry and Veterinary Service, Karnataka. Unpublished M.Sc. thesis, University of Agricultural Sciences, Dharwad, Karnataka.
Tayade, A., Chinchmalatpure, U.R $\&$ Supe, S.V. (2011). Information and Communication Technology used by the Scientists in Krishi Vigyan Kendra and Regional Research Centre. Journal of Global Communication, 4 (1) 16-26. 